\title{
Peranan Humor terhadap Stres dengan Subjective Well Being (SWB) sebagai Mediator pada Dewasa Awal
}

\author{
Erik Wijaya \\ Jurusan Psikologi, Universitas Tarumanagara Jakarta \\ Email: erikw@fpsi.untar.ac.id
}

\begin{abstract}
ABSTRAK
Penelitian ini ingin menguji peran humor stres dengan subjektif kesejahteraan sebagai variabel mediator pada dewasa awal. Penelitian tentang humor di Indonesia telah dilakukan dengan melibatkan subjek mahasiswa yang sedang menulis tesis, seorang mahasiswa pada tahun pertama, mahasiswa pascasarjana, serta pada masa dewasa tengah. Berdasarkan ini, para peneliti ingin melakukan penelitian lebih lanjut untuk menekankan peran humor dengan subjektif kesejahteraan (SWB) sebagai mediator pada awal masa dewasa awal. Penelitian dilakukan pada awal masa dewasa karena sumber-sumber stres dari pekerjaan yang dilakukan dan keluarga hidup sebagai bagian dari tugas-tugas perkembangan. Berdasarkan hasil penelitian ini ditemukan subjective well being memiliki peran sebagai variabel mediator dari humor superiority terhadap stres.
\end{abstract}

Kata kunci: humor, subjective well being (swb), stress.

\section{PENDAHULUAN}

Hidup yang sehat pada masa dewasa awal seringkali terganggu karena adanya dinamika kehidupan di tahap ini yang dapat mengarahkan individu pada stres. Usia dewasa awal merupakan tahapan seseorang mulai menjalin hubungan yang intim dan pribadi seperti pernikahan (Papalia, Feldman, \& Martorell, 2012). Berdasarkan hal tersebut, mereka bisa mengalami stres dikarenakan adanya konflik dari peran ganda yang dijalaninya sebagai pasangan suami istri, orang tua, dan pekerja (Kolak \& Vernon-Feagans, 2008). Berdasarkan hal tersebut maka untuk mengatasi stres salah satunya adalah dengan berhumor.

Menurut Driver (dalam Hartanti, 2008), humor merupakan sifat dari sesuatu atau suatu situasi yang kompleks yang menimbulkan keinginan untuk tertawa. Secara sederhana humor didefinisikan sebagai sesuatu yang lucu. Eysenck (dikutip dalam Utomo, 2009) menyebutkan humor adalah sesuatu yang dapat membuat tertawa. Hasanat dan Subandi (1998) mengatakan humor dinilai dapat menimbulkan emosi positif, sebab humor menjadikan seseorang dapat tersenyum ataupun tertawa dan memunculkan emosi positif. Humor dapat membuat seseorang menjadi lebih rileks, tidak tegang, sehingga pikiran pun dapat lebih berkonsentrasi untuk menyelesaikan masalah.

Humor secara umum dapat membantu seseorang dalam menurunkan perasaan negatif yang membuat seorang individu mengalami stres dalam kehidupannya (Greenberg, 2007). Menurut Maslow dan Allport (dikutip dalam Suyasa, 2010), salah satu ciri orang yang dewasa yaitu dapat menggunakan humor dengan tujuan bukan untuk mengejek atau menghina kekurangan atau penderitaan orang lain melainkan untuk membantu individu tersebut dalam menerima diri sendiri. Pada penelitian McCrae (dikutip dalam Weiten, Dunn, \& Hammer, 2012) ditemukan bahwa $40 \%$ partisipan penelitiannya dapat menggunakan humor untuk mengatasi stres yang dialaminya dalam hidup. Selanjutnya berdasarkan penelitian meta analisis yang dilakukan Hartanti (2008), hasilnya menunjukkan bahwa selera humor terbukti dapat menurunkan stres dan menimbulkan efek positif bagi kesehatan fisik dan psikis seseorang.

Penyelesaian masalah dan munculnya emosi positif merupakan faktor-faktor dalam komponen kebahagiaan yang dikenal dengan subjective well being (SWB). Diener dan Tay (2015) mengemukakan bahwa SWB merupakan suatu keadaan individu baik secara kognitif yang 
ditandai dengan adanya kepuasan terhadap hidupnya, baik secara umum maupun spesifik pada domain tertentu, maupun secara afektif yakni mengalami afeksi positif lebih sering dari afeksi negatif. Penyelidikan terhadap keadaan ini dilakukan secara subyektif pada individu yang bersangkutan terhadap keseluruhan dalam pengalaman hidupnya. Secara umum Diener (1984; 1994) menguraikan SWB terdiri atas empat dimensi, yaitu: (1) Positive affect, (2) Negative affect, (3) Global Life Satisfaction, (4) Domain Life Satisfaction.

Selanjutnya Diener, Lucas, Oishi, dan Shu (2002) juga menemukan bahwa orang yang bahagia cenderung lebih melihat pada pengalaman positif yang dialami dalam hidupnya, sementara orang yang tidak bahagia cenderung lebih memfokuskan pada domain hidup yang paling menyulitkan. Perbedaan proses ini memberikan implikasi yang jelas mengenai hidup setiap individu dalam membangun tingkat SWB-nya secara keseluruhan.

Penelitian tentang humor dengan aspek psikologis kebahagiaan sudah ada sebelumnya diantaranya penelitian dari penelitian Hartanti (2008), humor cenderung menurunkan stres dan menimbulkan efek positif bagi kesehatan fisik maupun psikis. Penelitian selanjutnya dari Rizzolo, Zipp, Stiskal, Simpkins (2009) juga menunjukkan bahwa yoga, humor, dan membaca dapat memiliki dampak yang sama dalam menurunkan stres akut pada mahasiswa pascasarjana. Penelitian yang dilakukan oleh Alfiani (2014) juga menunjukkan hasil yang sama bahwa humor dapat menurunkan tingkat stres pada mahasiswa secara signifikan.

Penelitian mengenai humor di Indonesia sudah pernah dilakukan dengan melibatkan subyek pada mahasiswa yang sedang menyusun skripsi (Tazraini, 2015), mahasiswa pada tahun pertama (Rumondor, 2007), mahasiswa pascasarjana (Rizzolo, et al. 2009), serta pada dewasa madya (Liliana, 2014). Berdasarkan hal tersebut, peneliti ingin melakukan penelitian lebih lanjut peranan humor terhadap stres dengan subjective well being (SWB) sebagai mediator pada dewasa awal.

\section{METODE PENELITIAN}

Pendekatan yang digunakan dalam penelitian ini adalah pendekatan kuantitatif. Selanjutnya penelitian ini pada dasarnya bertujuan untuk melihat adanya peranan humor terhadap stres dengan SWB sebagai mediator pada dewasa awal. Partisipan dipilih dengan metode convenience sampling. Subjek sebagai partisipan adalah individu berusia 20-40 tahun, jenis kelamin, tingkat pendidikan, agama dan status sosial ekonomi tidak dibatasi. Jumlah responden sebanyak 200 orang (terdiri dari 100 dari instansi swasta dan 100 negeri) dewasa awal yang akan diambil dari tiga sekolah di Jakarta.

\section{HASIL DAN PEMBAHASAN}

\section{Gambaran Partisipan}

Pada bagian ini diberikan gambaran dari partisipan. Gambaran partisipan ini pertama adalah berdasarkan jenis kelamin. Berdasarkan data yang diperoleh mengenai jenis kelamin partisipan, jumlah laki-laki sejumlah 106 orang subyek (53\%) dan perempuan sebanyak 94 orang (47\%). Untuk lebih jelasnya dapat dilihat pada Tabel 1.

Tabel 1. Gambaran partisipan berdasarkan jenis kelamin

\begin{tabular}{ccc}
\hline Jenis_Kelamin & Frekuensi & Persentase \\
\hline Laki-laki & 106 & 53.0 \\
Perempuan & 94 & 47.0 \\
\hline Total & 200 & 100.0 \\
\hline
\end{tabular}


Gambaran partisipan kedua adalah berdasarkan agama yang dianut. Berdasarkan data yang diperoleh mengenai agama partisipan, jumlah terbanyak adalah beragama Islam sejumlah 178 orang (89\%) dan paling sedikit beragama Katholik dan Buddha masing-masing sebanyak 4 orang (2\%). Untuk lebih jelasnya dapat dilihat pada Tabel 2.

Tabel 2. Gambaran partisipan berdasarkan agama

\begin{tabular}{ccc}
\hline Agama & Frekuensi & Persentase \\
\hline Islam & 178 & 89.0 \\
Protestan & 14 & 7.0 \\
Katholik & 4 & 2.0 \\
Buddha & 4 & 2.0 \\
\hline Total & 200 & 100 \\
\hline
\end{tabular}

Gambaran partisipan ketiga adalah berdasarkan pendidikan terakhir. Berdasarkan data yang diperoleh mengenai pendidikan akhir partisipan, jumlah terbanyak adalah memiliki pendidikan terakhir S1 sejumlah 103 orang subyek $(51,5 \%)$ dan subyek paling sedikit berpendidikan S2 sebanyak 27 orang (13,5\%). Untuk lebih jelasnya dapat dilihat pada Tabel 3.

Tabel 3. Gambaran partisipan berdasarkan pendidikan terakhir

\begin{tabular}{ccc}
\hline Pendidikan Terakhir & Frekuensi & Persentase \\
\hline D1/D2/D3 & 70 & 35.0 \\
S1 & 103 & 51.5 \\
S2 & 27 & 13.5 \\
\hline Total & 200 & 100 \\
\hline
\end{tabular}

Gambaran partisipan keempat adalah berdasarkan penghasilan. Berdasarkan data yang diperoleh mengenai penghasilan partisipan, jumlah terbanyak adalah memiliki penghasilan Rp. 2.500.000 - Rp. 5.000 .000 sejumlah 112 orang partisipan (56\%) dan subyek paling sedikit berpenghasilan $>$ Rp. 10.000 .000 sebanyak 12 orang partisipan (6\%). Untuk lebih jelasnya dapat dilihat pada Tabel 4.

Tabel 4. Gambaran partisipan berdasarkan penghasilan

\begin{tabular}{ccc}
\hline Penghasilan & Frekuensi & Persentase \\
\hline < Rp. 2.500 .000 & 31 & 15.5 \\
Rp. 2.500 .000 - Rp. 5.000 .000 & 112 & 56.0 \\
Rp. 5.000 .000 - Rp. 7.500 .000 & 28 & 14.0 \\
Rp. 7.500 .000 - Rp. 10.000 .000 & 17 & 8.5 \\
> Rp. 10.000 .000 & 12 & 6.0 \\
\hline Total & 200 & 100 \\
\hline
\end{tabular}

\section{Gambaran Data dan Penggolongan Variabel Penelitian}

Pada bagian ini akan dibahas mengenai gambaran variabel penelitian. Gambaran data untuk variabel stres menggunakan skala 1-5 memiliki mean hipotetik alat ukur yaitu 3, sedangkan mean empirik adalah 2.2693. Skor mean empirik lebih kecil dibandingkan dengan skor mean hipotetik dengan demikian maka stres subjek dapat dikatakan rendah.

Gambaran selanjutnya yaitu variabel subjective well being (SWB) menggunakan skala 1-4 memiliki mean hipotetik alat ukur yaitu 2.5, sedangkan mean empirik adalah 3.0965. Skor mean 
empirik lebih besar dibandingkan dengan skor mean hipotetik dengan demikian maka SWB subjek dapat dikatakan tinggi.

Gambaran selanjutnya yaitu variabel humor menggunakan skala 1-5 memiliki mean hipotetik alat ukur yaitu 3, sedangkan mean empirik pada humor netral adalah 3.6045, humor cognitive adalah 3.2982 dan humor superiority adalah 3.1725. Skor mean empirik lebih besar dibandingkan dengan skor mean hipotetik dengan demikian maka humor subjek dapat dikatakan tinggi dan yang paling tinggi/dominan pada rata-rata partisipan adalah humor netral. Sebagai rangkuman mengenai gambaran umum dari masing-masing variabel penelitian dapat dilihat pada Tabel 5.

Tabel 5. Gambaran variabel penelitian

\begin{tabular}{lcc}
\hline \multicolumn{1}{c}{ Variabel Penelitian } & Mean Empirik & Mean Hipotetik \\
\hline STRES & 2.2693 & 3.0 \\
Subjective Well Being (SWB) & 3.0965 & 2.5 \\
HUMOR_NETRAL & 3.6045 & 3.0 \\
HUMOR_COGNITIVE & 3.2982 & 3.0 \\
HUMOR_SUPERIORITY & 3.1725 & 3.0 \\
\hline
\end{tabular}

\section{Uji Normalitas Variabel Penelitian}

Berdasarkan data yang diperoleh, uji normalitas data dilakukan terhadap variabel penelitian. Uji normalitas data menggunakan One Sample Kolmogorov-Smirnov. Pada variabel stres, nilai Z = $1.229, p>0.05$ sehingga penyebaran data untuk stres terdistribusi normal. Pada variabel SWB, nilai $\mathrm{Z}=0.662, p>0.05$ sehingga penyebaran data untuk variabel SWB terdistribusi normal. Kemudian pada humor netral, nilai $Z=1.180, p>0.05$ sehingga penyebaran data untuk variabel humor netral terdistribusi normal. Sedangkan pada humor cognitive, nilai $\mathrm{Z}=1.108, p>0.05$ sehingga penyebaran data untuk variabel humor cognitive terdistribusi normal. Terakhir pada humor superiority, nilai $\mathrm{Z}=0.894, p>0.05$ sehingga penyebaran data untuk variabel humor superiority terdistribusi normal. Berdasarkan uji normalitas pada berbagai variabel penelitian, maka pengujian hipotesis penelitian untuk menguji mediasi dari variabel menggunakan regresi linear dapat dilakukan. Hasil uji normalitas dapat dilihat secara detail pada Tabel 6.

Tabel 6. Hasil uji normalitas variabel penelitian

\begin{tabular}{lcc}
\hline \multicolumn{1}{c}{ Variabel } & Kolmogorov-Smirnov $Z$ & $\mathrm{p}$ \\
\hline Stres & 1.229 & 0.097 \\
SWB & 0.662 & 0.774 \\
Humor Netral & 1.180 & 0.124 \\
Humor Cognitive & 1.108 & 0.172 \\
Humor Superiority & 0.894 & 0.401 \\
\hline
\end{tabular}

\section{Pengujian Hipotesis Penelitian}

Pada bagian ini akan dibahas mengenai pengujian hipotesis penelitian. Pengujian hipotesis pada penelitian ini untuk membuktikan peranan SWB sebagai mediator hubungan humor terhadap stres. Pengujian pertama dilakukan pada humor netral dengan gambar peranan terdapat pada gambar 1. 


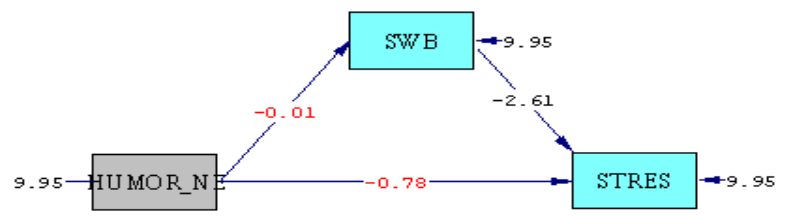

Chi-Square $=0.00, d f=0, P-v a l u e=1.00000$, RMSEA $=0.000$

Gambar 1. Output t Values Peranan Humor Netral terhadap Stres yang Dimediasi SWB

Berdasarkan hasil analisa data dengan menggunakan bantuan program LISREL 8.8 diketahui bahwa dari hasil $\mathrm{t}$ values dapat dilihat bahwa peranan humor netral terhadap stres tidak signifikan karena nilai $t<-1.96$ (terlihat warna merah pada panah peranannya), demikian pula peranan humor netral terhadap SWB juga tidak signifikan karena nilai $t<1.96$ (terlihat warna merah pada panah peranannya). Dari hasil tersebut yang signifikan hanya peranan SWB terhadap stres dengan nilai $t=-2.61>-1.96$. Berdasarkan hal tersebut dapat dilihat bahwa pola hubungan antar variabel terutama SWB tidak memediasi hubungan antara humor netral dan stres. Hasil selanjutnya dilakukan pada humor cognitive dengan gambar peranan terdapat pada gambar 2 .

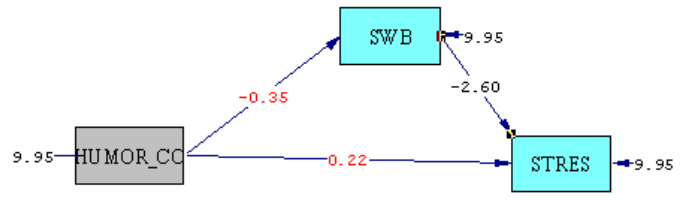

Chi-square=0.00, df=0, P-value=1.00000, RMSEA $=0.000$

Gambar 2. Output t Values Peranan Humor Cognitive terhadap Stres yang Dimediasi SWB

Berdasarkan hasil analisa data dengan menggunakan bantuan program LISREL 8.8 diketahui bahwa dari hasil $\mathrm{t}$ values dapat dilihat bahwa peranan humor cognitive terhadap stres tidak signifikan karena nilai $t<-1.96$ (terlihat warna merah pada panah peranannya), demikian pula peranan humor cognitive terhadap SWB juga tidak signifikan karena nilai $t<1.96$ (terlihat warna merah pada panah peranannya). Dari hasil tersebut yang signifikan hanya peranan SWB terhadap stres dengan nilai $t=-2.60>-1.96$. Berdasarkan hal tersebut dapat dilihat bahwa pola hubungan antar variabel terutama SWB tidak memediasi hubungan antara humor cognitive dan stres. Hasil selanjutnya dilakukan pada humor superiority dengan gambar peranan terdapat pada gambar 3 .

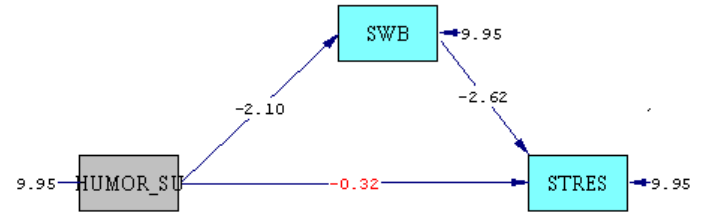

Chi-Square=0.00, df=0, P-value=1.00000, RMSEA=0.000

Gambar 3. Output t Values Peranan Humor Superiority terhadap Stres yang Dimediasi SWB

Berdasarkan hasil analisa data dengan menggunakan bantuan program LISREL 8.8 diketahui bahwa dari hasil $t$ values dapat dilihat bahwa peranan humor superiority terhadap stres tidak signifikan karena nilai $\mathrm{t}<-1.96$ (terlihat warna merah pada panah peranannya). Kemudian peranan humor superiority terhadap SWB signifikan karena nilai $t=-2.10>-1.96$. Terakhir peranan SWB terhadap stres dengan nilai $t=-2.62>-1.96$. Berdasarkan hal tersebut dapat dilihat bahwa pola hubungan antar variabel terutama SWB memediasi hubungan antara humor superiority dan stres. Mediasi yang terbentuk juga mediasi sempurna (full mediation) karena 
ketika melalui SWB peranan menjadi lebih signifikan sehingga membuat peranan humor superiority terhadap stres menjadi tidak signifikan.

\section{KESIMPULAN}

Berdasarkan hasil pengolahan data diperoleh hasil bahwa ternyata ditemukan adanya peranan negatif dan signifikan humor superiority terhadap SWB. Dengan demikian hal ini menunjukkan bahwa apabila SWB tinggi maka humor superiority menjadi rendah, begitu juga sebaliknya apabila SWB rendah maka humor superiority menjadi tinggi.

Selanjutnya berdasarkan hasil pengolahan data diperoleh hasil bahwa ternyata ditemukan adanya peranan negatif dan signifikan SWB terhadap stres. Dengan demikian hal ini menunjukkan bahwa apabila SWB tinggi maka stres menjadi rendah, begitu juga sebaliknya apabila SWB rendah maka stres menjadi tinggi. Sedangkan untuk peranan humor superiority terhadap stres tidak signifikan. Dengan demikian maka terbentuk mediasi sempurna humor superiority melalui SWB.

\section{Pembahasan}

Berdasarkan hasil ditemukan SWB memediasi peranan humor superiority terhadap stres pada dewasa awal. Dengan demikian dapat dilihat bahwa individu yang memiliki SWB tinggi lebih banyak tidak mengembangkan humor yang dengan tipe humor yang suka menyakiti pihak lain. Tipe humor ini jika dilihat dari konstruk butir nya maka dapat dilihat humor ini hanya melihat sesuatu yang lucu dengan stimulus kesulitan pada kehidupan pihak lain (pengelolaan humor terdapat sifat menjelekkan serta merendahkan pihak lain dalam hidup dengan menertawakannya). Dengan demikian pola hubungan yang terbentuk adalah ketika individu menggunakan humor superiority maka kebahagiaan yang diperoleh akan rendah sehingga menimbulkan stres yang tinggi. Sebaliknya jika seorang individu tidak menggunakan humor superiority maka kebahagiaan yang diperoleh akan tinggi sehingga menimbulkan stres yang rendah.

Hasil ini sejalan dengan Martin (2007) yang mengungkapkan bahwa menggunakan humor untuk menjatuhkan diri sendiri (self-defeating humor) cenderung memiliki perilaku stres yang tinggi. Demikian juga dengan Diener, Lucas, Oishi, dan Shu (2002) yang menemukan bahwa orang bahagia cenderung melihat pada pengalaman positif yang dialami dalam hidupnya, sementara orang yang tidak bahagia cenderung memfokuskan pada domain hidup yang paling menyulitkan. Perbedaan proses ini memberikan implikasi yang jelas mengenai hidup setiap individu dalam membangun tingkat SWB-nya secara keseluruhan. Selain itu juga temuan hasil penelitian tersebut juga diperkuat oleh penelitian yang dilakukan oleh Rumondor (2007) dan Nataatmaja (2012) dengan hasil yang sama bahwa humor yang bersifat affiliative memiliki korelasi negatif dengan stres dan humor yang bersifat self-defeating memiliki korelasi positif dengan stres. Dengan demikian dapat dilihat bahwa humor superiority akan mencerminkan orang yang merasakan perasaan negatif, sehingga penggunaan humor jenis ini sekaligus menunjukkan adanya dominasi perasaan tidak bahagia.

Penelitian ini memiliki beberapa keterbatasan diantaranya teknik sampling yang digunakan adalah convenience. Dengan demikian sampel di dalam penelitian ini merupakan sampel yang diambil dengan kemudahan sehingga tidak proporsional menggambarkan dewasa awal yang ada di Jabodetabek. Selain itu dalam penelitian ini, tidak dikontrol variabel lain yang memiliki kemungkinan untuk diprediksi hubungannya variabel psikologi positif lain seperti quality of life, 
psychological well being (PWB). Dengan demikian penelitian ini perlu dilakukan penyempurnaan dengan meneliti hubungan dengan variabel psikologi positif lainnya.

\section{Saran Teoretis}

Secara teoretis penelitian ini memberikan manfaat bagi perkembangan ilmu psikologi terutama ilmu psikologi perkembangan dewasa awal serta psikologi sosial. Dengan adanya penelitian ini maka secara teoretis bidang ilmu tersebut memeroleh manfaat dengan adanya fakta hasil penelitian sehingga secara empiris teori-teori menjadi ada buktinya. Penelitian ini memberikan pembuktian secara teoretis bahwa peranan humor superiority terhadap stres dapat dimediasi oleh SWB. Selain itu temuan dalam penelitian ini membuktikan bahwa humor superiority akan menimbulkan rendahnya SWB, oleh karena itu tidak disarankan untuk menggunakan jenis humor ini dengan tujuan meredakan stres pada kondisi sehari-hari.

Saran secara teoretis terutama untuk penelitian selanjutnya diharapkan dapat meneliti peranan humor dengan variabel psikologi positif lain yang memungkinkan untuk diuji sebagai prediktif variabel berikutnya. Variabel lainnya tersebut misalnya quality of life, psychological well being (PWB) atau dikarenakan penelitian ini mengambil setting di lingkungan sekolah karena melibatkan subyek yang bekerja sebagai guru dapat dikaitkan juga dengan variabel school well being.

\section{Saran Praktis}

Saran secara praktis peneliti berikan kepada para dewasa awal dapat terus mengembangkan SWB serta komponen yang terkandung di dalamnya (meningkatkan perasaan positif dan melepaskan perasaan negatif) salah satunya dengan cara mengembangkan humor yang positif. Oleh karena itu, dewasa awal senantiasa dapat mengembangkan SWB dengan baik dengan mengurangi humor yang bersifat menyakiti pihak lain. Humor yang dikembangkan oleh individu yang memiliki SWB positif merupakan humor yang positif. Dengan demikian perasaan positif akan memberikan efek kepada suasana hati yang baik dan akan memunculkan humor yang cerdas tanpa menyakiti pihak lain sehingga dapat memeroleh kebahagiaan sehingga dapat meredakan stres yang dialami dalam kehidupan sehari-hari.

\section{Ucapan Terima Kasih (Acknowledgement)}

Peneliti mengucapkan terima kasih kepada Direktorat Penelitian dan Pengabdian kepada Masyarakat (DPPM) UNTAR yang telah mendanai dan menfasilitasi untuk publikasi penelitian ini.

\section{REFERENSI}

Alfiani, V. (2014). Pengaruh humor terhadap stres pada mahasiswa tingkat akhir yang mengerjakan skripsi di universitas brawijaya malang. Skripsi. Universitas Brawijaya. Malang.

Diener, E. (1984). Subjective well-being. Psychological Bulletin, 95, 542-575.

Diener, E. (1994). Assessing subjective well-being: Progress and opportunities. Social Indicators Research, 31, 103-157.

Diener, E., Fujita, F., Tay, L., \& Biswar-Diener, R. (2011). Purpose, mood, and pleasure in predicting satisfaction judgements. Organizational Research Methods, 18(4), 203-221.

Diener, E., Lucas, R. E., Oishi, S., \& Suh, E. M. (2002). Looking up and down: Weighting good and bad information in life satisfaction judgements. Personality and Social Psychology Bulletin, 28, 437-445.

Greenberg, J. S. (2007). Comprehensive stress management $\left(9^{\text {th }}\right.$ ed.). New York, NY: McGrawHill. 
Hasanat, N.U. \& Subandi. (1998) Pengembangan alat kepekaan terhadap humor. Jurnal Psikologi. Tahun XXV No. 1, hlm 45-52.

Hartanti. (2008). Apakah selera humor menurunkan stres? Sebuah meta-analisis. Anima, Indonesian Psychological Journal. Vol. 24 (1) 38-55.

Kolak, A. M., \& Vernon-Feagans, L. (2008). Familiy-level coparenting processess and child gender as moderators of family stress and toddler adjustment. Infant and Child Development, 17. DOI: 10.1002/icd.

Looker, T., \& Gregson, O. (2005). Managing stress: Mengatasi stres secara mandiri. Surabaya: Baca.

Liliana. (2014). Hubungan antara humor styles dan kepuasan pernikahan pada dewasa madya di Jakarta. Skripsi. Universitas Bina Nusantara. Jakarta.

Muslimah.(2015, 29 Juli).Ketika istri harus berperan ganda. Diunduh dari http://www.fimadani.com/ketika-istri-harus-berperan-ganda/.

Papalia, D. E., Feldman, R. D., \& Martorell, G. (2012). Experience human development $\left(12^{\text {th }}\right.$ ed.). New York, NY: McGraw Hill.

Rumondor, P. C. B. (2007). Hubungan dimensi humor styles dengan stres pada mahasiswa tahun pertama. Skripsi. Universitas Indonesia. Depok.

Rizzolo, D., Zipp, G. P., Stiskal, D., \& Simpkins, S. (2009). Stress management strategies for students: The immediate effects of yoga, humor, and reading on stress. Journal of College Teaching \& Learning. 6(8).79-88.

Suyasa, P. T. Y. S. (2010). Indentity type of humor: Funy, funy and funy. Temu Ilmiah Nasional Psikologi, Jakarta 5 Agustus 2010.

Tazraini. (2015). Hubungan antara humor style dengan tingkat stres dalam menyusun skripsi pada mahasiswa unsyiah.Skripsi. Universitas Syiah Kuala. Banda Aceh.

Utomo, U. H. N. (2009). Sense of humor: Studi psikometris tentang skala kepekaan terhadap humor versi a dan b. Laporan Penelitian. (tidak diterbitkan). Yogyakarta: Universitas Ahmad Dahlan.

Weiten, W., Dunn, D. S., \& Hammer, E. Y. (2012). Psychological applied to modern life: Adjustment in the $21^{\text {st }}$ century (10 ${ }^{\text {th }}$ ed.). Belmont, CA: Wadsworth. 